\title{
Institutions and Economic Growth in the Atlantic Periphery: The Efficiency of the Portuguese Machinery of Justice, 1870-1910 ${ }^{1}$
}

\author{
Jaime Reis \\ Instituto de Ciências Sociais \\ Universidade de Lisboa \\ jaime.reis@ics.ul.pt
}

Paper presented to the conference on Law and Economic Development: An Historical

Perspective: Utrecht, Utrecht University, 20-22 September 2007

\footnotetext{
${ }^{1}$ The author is grateful to Helena Monteiro and Rui Lopes for research into archival sources. For useful advice and comments, he is indebted to Patrick Svensson, Dan Andersen, Timothy Guinnane, Hans Christian Johansen, Anders Perlinge, Ingrid Henriksen, Juan Carmona and Hadi Esfahani, as well as to the participants in the Economic History seminar at the Universidad Carlos III, Madrid.
} 
The comparative economic performance of nations over the long run has been a major field of interest for some time now, both in Economic History and in Growth Economics. Thanks to the recent availability of macro-economic data for many Western countries, its analysis has become possible using endogenous models which take into account the usual variables in the Solow formulation plus control variables, such as human capital, technology or social capability. Whilst recognizing the importance of institutional factors, economic historians have appeared reluctant, however, to incorporate them formally into their equations. ${ }^{2}$ This is particularly evident in the abundant historical literature on the economics of growth and convergence during the so-called 'first era of globalization' (Bordo, Taylor, and Williamson, 2003; Pamuk and Williamson, 2000; O’Rourke and Williamson, 1999 and 1997; Baumol, 1986). ${ }^{3}$ The classic work by O'Rourke and Williamson (1999), which quantifies in detail the causes of catch-up and convergence within the late nineteenth century Atlantic economy, dismisses institutional influences on the grounds that open economy forces provide adequate explanation for the differential behaviour of these economies. The assumption is that during the nineteenth century 'the State took a broadly liberal policy stance' (p.14) and institutional divergence among nations can therefore be treated as marginal to the problem under consideration.

\section{[table 1 about here]}

\footnotetext{
${ }^{2}$ For an excellent survey of the potential and missed opportunities of this literature, see Crafts (2000).

${ }^{3}$ For interesting exceptions, see the papers by Foreman-Peck (1995), Foreman-Peck and Lains (2000) and Allen (2003).
} 
The available evidence on the European countries that composed the $19^{\text {th }}$ century Atlantic economy does not support, however, this notion of homogeneity. Table 1 gathers quantitative data on various aspects of institutional development for sixteen of the countries included in the O'Rourke and Williamson (1999) sample. ${ }^{4}$ Column 1 presents an indicator of the 'openness' of their public decision-making arrangements constructed by the University of Maryland's Polity-IV project. ${ }^{5}$ Column 2 shows the extent of popular involvement in their political systems, through elections, as measured by the diffusion of the franchise. ${ }^{6}$ Column 3 displays an index of 'contract-intensive money' (CIM) devised by Clague et al (1999), which proxies the public's trust in the institutions that protect property rights and enforce contracts. ${ }^{7}$ In all of them, we find a considerable dispersion around the mean which suggests that the diversity of institutional endowments may have been considerable. This in turn would mean that institutions might well have a greater role to play in explaining the patterns of long term economic growth than has been thought likely.

Several difficulties arise, however, when we try to pursue these connections. One is that preliminary tests show that none of the variables in table 1 in fact helps to improve the results of the convergence equations estimated by O'Rourke and Williamson. ${ }^{8}$ Other, more appropriate ones must therefore be found. This raises a second problem which is the difficulty of constructing adequate metrics to proxy, retrospectively, the various

\footnotetext{
${ }^{4}$ To avoid problems of endogeneity, we relate these data to 1870 , the start of the observed process of growth and convergence.

${ }^{5}$ On a scale from -10 to +10 , Polity-IV measures to what degree the political system suppresses or fosters the competitive political participation of the citizenry in the choice of leaders and policies and ensures the protection of civil liberties. See Marshall and Jaggers (2002) and, for the data, http://www.cidcm.umd.edu/polity/.

${ }^{6}$ Data for the franchise as a percentage of the adult population is obtained from Rose (2000), except in the case of Greece, which was kindly provided by Professor Anne Couderc.

7 'Contract-intensive money' is defined as the ratio of non-currency money to total money supply, i.e. $\mathrm{CIM}=(\mathrm{M} 2-\mathrm{C}) / \mathrm{M} 2)$. The closer its value is to 1 , the greater the trust that the public will have in the protection that institutions give to contractual rights. It is estimated using data from Mitchell (1996).

${ }^{8}$ See Reis (2005a). In the case of CIM, the results of the estimation are suggestive but difficulties arise from the problem of endogeneity posed in this context by 'contract-intensive money'. For a different view of this issue, see Prados and Sanz (2006).
} 
forms of institutional input which could be important for growth. As has been quite correctly observed, 'institutions have to a large extent been left out of the analysis [of economic development] for the reason that they are difficult to assess within a strictly defined theoretical framework and equally difficult to measure in quantitative terms' (Gunnarsson, 1991: 43). A further twist is that what differentiated nations, in late nineteenth century Western Europe, was how well these institutions functioned, not so much how well they were structured, a point which has also been made with regard to the present day (Rodrick et al., 2004). Formal distinctions between the institutions of these states certainly existed but were far from substantial. This is not surprising bearing in mind that their respective institutional architectures and philosophies of government were shaped by a common Liberal parliamentary blueprint (Finer, 1997). What we try here therefore is to focus on the more relevant but elusive aspects of institutional quality, rather than on the more measurable but less significant ones of form.

The aim of this chapter is to propose an indicator of institutional efficiency which does not suffer from the shortcomings noted above and can be useful to economic historians of institutions in general. It must be objective, quantifiable and allow comparisons over time and space. We shall try and achieve this by assessing the effectiveness of the judicial system in protecting property rights and enforcing contracts, a key issue in the debate concerning the contribution of institutions to economic growth. This will be carried out in the historical context of Portugal, a small and backward economy of the Atlantic periphery during the 'first era of globalization' (1870-1913). ${ }^{9}$ The next section

\footnotetext{
${ }^{9}$ Two studies have been seminal in their treatment of the links between institutions and long term economic development, namely Acemoglu, Johnson and Robinson (2001 and 2002). The present analysis differs from their approach in several ways. It considers a much shorter time span -40 as opposed to 500 years. Its object of study is not a sample of ex-colonies of the West which adopted imported institutions, but rather European countries which set up and developed their own. Most important, it employs measures of institutional efficiency which are appropriate to the historical situation, rather than yardsticks drawn from the late $20^{\text {th }}$ century or from the Polity project, none of which seem suitable to the context examined. For a recent critique of this approach, particularly regarding the institutionalist assumption of country-specific and time-invariant institutions and legal codes, see Sgard (2006).
} 
of this paper describes the model to be used and justifies the variable - the price of mortgage credit - chosen as a proxy for the 'quality' of Portuguese justice in the late nineteenth century. This choice is guided by North (1990)'s suggestion that 'the level of interest rates in capital markets is perhaps the most evident quantitative dimension of the efficiency of the institutional framework' (p.69). The third section presents the data collected in order to test the relationship under analysis and describes the applicable legal framework. The fourth section presents and discusses the results of the estimation. The last section concludes that the proposed approach provides a credible yardstick for measuring the effectiveness of the Portuguese courts of law and, by extension, of other systems of justice too. Having found that economic agents had a low regard for the ability of the judicial system to ensure the satisfactory enforcement of contracts, it further notes that this perception does not seem to have noticeably improved over time. Finally, it suggests the point at which Portugal may have stood in a rough international ranking of how several countries scored in terms of the quality of their systems of justice.

\section{II}

An adequate protection of property and contractual rights has long been recognized as an essential part of the contribution of institutions to economic performance (Glaeser et al., 2004; Mauro, 1995). As Adam Smith (1776) commented, 'commerce and manufactures... can seldom flourish in any state in which there is not a certain degree of confidence in the justice of government'. Its absence has a negative effect on investment in fixed and human capital, and in research and technological innovation, which are crucial for growth and development (Nelson and Sampat, 2001). It also deters savers 
from acquiring stores of wealth and thereby discourage economic agents from pursuing profitable activities and seeking better results from their efforts. Above all, it holds back the spread of the division of labour and specialization which is critical to all modern economic growth (North, 1990).

A satisfactory degree of judicial protection for property and contracts depends on two conditions. It requires, on the one hand, a clear and sufficient body of rules and, on the other, a third-party agency which applies them fairly, expeditiously and at a low cost. In order that the operation of the courts be facilitated, it is also necessary that arrangements should exist whereby contracts can be easily documented, certified and registered and, in the case of property rights, that economic agents can identify them and their holders easily and unequivocally. In both these functions, expectations are important. Measures protective of property and contractual rights must therefore not only be 'good'. They must also be stable over time and predictable, so that economic agents can project past experience in a consistent fashion and thus maximize the beneficial effect of the system of justice. $^{10}$

Assessing the output of a country's machinery of justice is not an easy matter. Judicial proceedings are often complex. The situations under scrutiny and the decisions produced by courts are far from homogeneous, and it is difficult to standardize them for the sake of quantification. Many of the indices used by the practitioners of the New Institutional Economics to quantify judicial efficiency are 'subjective'. They are based on surveys and polls which ask questions like 'how badly do economic agents think the judicial system functions?' and are therefore unsuitable for historical situations. Moreover, typically, they convert qualitative assessments into numbers with the use of

\footnotetext{
${ }^{10}$ The present study, whilst recognizing the importance of distinguishing between the quality of rules and the quality of their application, does not attempt to unbundle them. This would be an arduous task that would not fit into the compass of this paper which engages solely in the outcome of the courts' efforts from the point of view of the consumers of this service.
} 
arbitrary scales. This poses formidable problems of additivity, interpretation and comparison over time and space. ${ }^{11}$ Another, this time 'objective' approach has been used with some success in cases where litigation covers easily defined, repeat events such as eviction orders or cheque collection, and makes it possible to gauge efficiency simply by means of devices like counting the time it takes to reach or enforce a verdict. This sort of method has been used in several recent studies but not, to my knowledge, in historical contexts in which, in all likelihood, it would be an excessively arduous task to carry out. ${ }^{12}$

An alternative, indirect solution is to estimate judicial output by measuring its impact on the decisions of economic agents who are active in the markets affected by these rulings. A price for a given good or service that was significantly different from what might be expected, should the courts have functioned 'normally', would indicate a failure in the protection of contractual rights, for example. Our objective is to apply this reasoning to a field in which abundant and reliable information is available and a certain amount of theoretical reflection has already been undertaken and can help us formulate a suitable model.

We have chosen for this exercise the market for micro-credit in a rural setting. This was a common situation throughout nineteenth century Europe, often bringing together a large number of borrowers and lenders, in operations which were typically small and mostly local. In such atomistic markets, where large participants were absent, it seems fair to assume that 'the playing field must have been level' for all involved. Neither creditors nor debtors would have expected to obtain loan prices that deviated from what

\footnotetext{
${ }^{11}$ For studies which illustrate the difficulties of assessing the quality of government in a sample of countries in this fashion, see La Porta et al (1999), Kauffman et al (2002) and Cabral and Pinheiro (1999). For the same problem regarding the phenomenon of 'corruption', see Mauro (1995).

${ }^{12}$ For an illustration of the enormous effort required to produce an 'objective' indicator, see Djankov et al (2003), which employs thirty eight variables to assess comparatively how well, during the 1990s, the courts of 115 countries functioned.
} 
might be called a 'normal' or competitive value. ${ }^{13}$ In the first instance, contract enforcement relied to a considerable extent on informal mechanisms associated with reputation and credibility (Guinnane, 1994 and 2001). When this failed to resolve situations of non-compliance, however, formal sanctions became necessary since a credit market, where unsanctioned default became easy and habitual, would soon be starved of capital and face rocketing interest rates. Hence the vital importance of courts of law that were able to adjudicate such conflicts rapidly and equitably. In cases where Justice was administered slowly, unfairly and with favouritism, the credit market was bound to function poorly, and the expression of this fact should be discernable in the behaviour of the price at which credit was allocated.

In markets plagued by the opportunism of borrowers, lenders have two ways of safeguarding the capital they tie up in loans. One is by requiring safe collateral, which can be executed with the help of third-party enforcement arrangements in the event of failure by the debtor to meet interest and repayment obligations. The other is to do without a real guarantee (which the borrower might be too poor to have, for example) and instead obtain information, at a cost, about the personal attributes of the potential debtor, which might be relevant to the probability of his defaulting. Reputation for honesty, being a hard and productive worker, having a good co-guarantor and so on should enable the lender to form a reasonable expectation concerning the borrower's commitment. This would form the basis on which the decision was taken to enter into a personal, unsecured loan and at what price.

In the present study, we deal only with the first of these alternatives. Mortgage credit between private parties offers an excellent opportunity for an analysis of how well

\footnotetext{
${ }^{13}$ We are not interested therefore in situations in which rural credit markets have become strongly influenced by financial institutions. Since the latter would enjoy economies of scale, they could lower the interest rate without this signifying an institutional improvement and this would invalidate the comparison we are trying to establish.
} 
Justice protects the rights of lenders. Firstly, it is only through the courts of law, which keep records, that creditors can foreclose on defaulting debtors and recover their principle. In the second place, to be effective, it requires a legally binding record between the parties, drawn up in accordance with a standard formula, and placed in safe-keeping. This means that a considerable amount of reliable, homogeneous information concerning both the contracts and those taking part in them has been generated and remains easily accessible for research.

In the model we outline below, the dependent variable is the market interest rate on this sort of loan, which is normally backed by secure assets, mostly land or buildings. Its main determinants are the cost of risk-free credit, an exogenous variable which is essentially stable over time; and a risk premium, the size and variance of which is governed by several factors. The most important one is the institutional setting, in particular the judicial system and its ability to protect and enforce contracts and property rights adequately. If this functions efficiently, the risk on such loans will be low and the rate charged should be close to the risk-free level. If this protection is perceived as inadequate by market operators, then the risk premium will be substantially greater than zero and the mean interest rate will rise accordingly. In this event, recognition of a low probability of recovering the loan, given the absence of an efficient independent third-party sanction, forces the lender to consider the personal attributes of the borrower when setting the conditions for the loan.

An adequate protection of the courts is a necessary but may not be a sufficient condition for mortgage credit to enjoy a low-risk status, however. Historically, there are occasions when the guarantee may be worth less than the principal. ${ }^{14}$ This would have left the creditor potentially at a disadvantage, in the event of non-compliance, and, as a result,

\footnotetext{
${ }^{14}$ Although not a majority, cases like this are not infrequent in the data base we are employing here,
} 
under the necessity of charging a higher risk premium. One would expect that the smaller the ratio between the guarantee and the amount borrowed, the greater this premium would have to be. Interestingly, although not a majority of the contracts considered here, many borrowers amongst those studied sought larger loans than their fixed assets could justify. This means that the relationship between the quality of justice and the price of credit is more complex than might be imagined at first sight.

Table 2 shows how the loan characteristics discussed above can be assembled into four categories in accordance with the two dichotomous criteria which are fundamental to the working of the mortgage credit market. The first separates operations into those in which the value of the guarantee is large enough to fulfil the contract in the case of default ('adequate guarantee'; and those in which it is not ('inadequate guarantee'). The data employed in applying this standard are observable and readily available. The second criterion distinguishes whether loans were made within a framework of effective enforcement of contracts by an independent system of justice ('good courts'); or not ('bad courts'). This is the variable which we cannot observe directly and therefore have to infer. To do so, we submit the loan information at our disposal to three independent statistical tests, which will tell us which of the two institutional alternatives - 'good' or 'bad' courts of law - best fits the evidence we have gathered. Before we define these tests, however, we must determine the implications, for the profile of this market, of belonging to each one of the panels in table 2 .

\section{[table 2 about here]}

We begin by looking at what would happen if the courts of law had been capable of giving satisfactory protection to the suppliers of financial services and, at the same time, 
borrowers had provided adequate collateral on the loans made (panel 1).To begin with, the interest rate level (r) would be typically low and fairly close to its risk-free level, in accordance with the security enjoyed by lenders vis-à-vis their debtors. The personal risk represented by individual borrowers being irrelevant to the determination of the price of the loan, the variance of $\mathbf{r}$ would also be low. Consequently, none of the personal attributes of borrowers noted above (vector A) would bear a statistically significant relationship to $\mathbf{r}$ either, as they would be unimportant for the recovery of the principal, should a default occur. Finally, the interest rate (r) and the guarantee/debt ratio (g) would be uncorrelated owing to the fact that above a 'safe' threshold for $\mathbf{g}$, the risk of the transaction would not be affected by its getting any larger. The lender would always recover his outlay, whatever the magnitude of this ratio ${ }^{15}$.

A second scenario (panel 2) would occur if the ratio $\mathbf{g}$ was less than the level that the market judged adequate. Though the judicial system was efficient in enforcing contracts and executing the collateral, in the event of a default, the lender would not recoup fully his loss in this way. This would require an interest rate (r) somewhat above that of a perfectly secure loan to compensate for the greater risk. For this reason also, one would expect that $\mathbf{r}$ would show a negative correlation with $\mathbf{g}$. In taking on this risk, however, the lender would also have to take into account the personal attributes (A) of the borrower, since they would affect the latter's capacity to meet the difference between the value of the loan outstanding and that of the security. The interest rate charged ought therefore to correlate with these attributes, and this would imply a higher degree of variance for $\mathbf{r}$ than found in panel 1.

A third possibility (panel 3) would be characterized by a high degree of incapacity of the machinery of justice to protect creditors' contractual rights, and by mortgage

\footnotetext{
${ }^{15}$ The situation depicted in panel 1 is not an 'ideal' one. As we shall see below, in several countries in late $19^{\text {th }}$ century Europe, though not in Portugal, mortgage credit actually seems to have conformed quite closely to these characterisitcs.
} 
guarantees being too low to ensure full repayment of the debt. In the event of default, lenders would have a low expectation of receiving any of the collateral in a reasonable delay. This would entail a high risk premium. The interest rate would be correspondingly high and would not bear any relation to the value of the collateral. Instead, it would be determined by the personal attributes (A) of the borrower, on which the chances of recovery of the principle would be based. In this case, $\mathbf{r}$ would also have a high variance.

Panel 4 shows what would happen if the courts failed to play their role properly as protectors of property and contractual rights, but this time with mortgage guarantees in excess of the value of the principal. The result would be both a level and a variance in the interest rate (r) significantly higher than one would expect to meet in a risk-free environment. The ratio $\mathbf{g}$ would once again have no influence on the level of $\mathbf{r}$, though not for the same reason as in panel 1. Rather it would be because no matter how great the value of the collateral, its practical importance for the lender's calculation was bound to be very small. In contrast, $\mathbf{r}$ would bear a significant relationship to the personal attributes of debtors (A) because these constituted the only information that lenders could rely on when gauging their chances of repayment by borrowers. ${ }^{16}$

This section's central claim then is that three simple quantitative tests arise from the schematic description in table 2 and provide us with the means to infer the 'goodness' of the judicial framework within which a given mortgage market might operate. Before applying them to our data, however, it is important to consider the information we shall be using and to summarize the legal context of late nineteenth century rural Portugal, which has been chosen as the proving ground for our hypothesis.

\footnotetext{
${ }^{16}$ It has to be accepted that lenders might not be uniformly regarded by the courts of law. Given the imperfections of the judicial system, some might be better at obtaining judicial protection than others. For this reason, in section III we include in vector $\mathbf{A}$ a variable that reflects possible differences of treatment of litigants by the courts.
} 
Although the nineteenth century expansion of financial services in Europe has been often thought of as an urban phenomenon, there was a rural dimension to it which had considerable significance too. Loans to farmers, landowners or simply to residents in the countryside, often financed from rural origins too, grew enormously in all countries during this period, and served to satisfy consumption needs, to adjust to life-cycle problems or to permit investment in additional agricultural capacity and new technology (Postel-Vinay. 1988; Guinane, 2001; Martinez Soto, 2001; Lindgren, 2002). Despite the rapid proliferation of institutional means, such as land banks, rural savings banks and rural credit cooperatives, much of this flow continued to occur through informal channels, involving only individuals and fairly simple contracts. Even in a 'financially sophisticated' country such as Sweden at the end of this century, informal credit was still about as important, in the provinces, as that undertaken by the corporate sector (Lindgren, 2002). Across the continent, mortgage loans, whether in the formal or the informal market, played an important part, but it is impossible to be precise regarding the share of total resources which they absorbed. Around 1900, in Spain, they accounted for 80 percent of all formal rural credit (Carmona and Simpson, 2003: 165), while in Italy mortgages outstanding were about equal to the total liabilities of all corporate financial institutions ${ }^{17}$. However, in the absence of data regarding 'personal credit', i.e. loans with no more backing than the borrower's signature, we cannot gauge what part mortgages were of total rural credit in any of these countries

\footnotetext{
${ }^{17}$ Data on mortgages for Italy are from the Annuario Statistico del Regno d'Italia for 1900. The total of corporate financial liabilities is from Reis (2005b).
} 
Portugal did not diverge from this pattern. Data on both mortgage and personal rural credit are scarce, unreliable and far from comprehensive. We lack any information on the extent of 'personal', unsecured credit, although impressionistic accounts suggest that, in the countryside, it was both substantial and much more expensive than mortgage credit. Indeed, the cry of 'usury' was a frequent one in connection with this form of finance (Ulrich, 1908; Esteves, 2002). What little we know regards mortgage credit. Only one national compilation is available, for the period 1852-1862. It shows that a total of about 35,000 contos was contracted during this decade in this form, ${ }^{18}$ which suggests the existence, by the early 1860 s, of a national stock of debt of the same order of magnitude. This can be compared to a total value of landed property at the time of around 400,000 contos (Vaz, 1863).

During the following decades, it seems that this portfolio must have grown to a fair extent, both in absolute terms and relative to the value of land. One indication is the creation in 1864 of the Companhia Geral de Crédito Português, to carry out long term operations (up to 60 years of duration) on the security of large estates (Marques, 1989). Altogether, 40,000 contos were loaned by this land bank between 1865 and 1909 and this was only a fraction of all mortgages in rural Portugal, since small and medium property was entirely by-passed by this institution. A second piece of evidence comes from the survey conducted on 54 of the country's circa 300 municipalities, in 1884, showing that between them their notaries had altogether 40,000 contos worth of hypothecary loans outstanding on their books (Rodrigues, 1929). A third comes from a handful of local studies which have revealed informal markets for this type of finance in the northern, central and southern rural parts of the country (Fonseca, 1977 and 1966; Vaquinhas, 1982; Vaquinhas and Fonseca, 1984; Bretell, 1991; Silva, 1994). The

\footnotetext{
${ }^{18}$ The real (plural $\underline{\text { reis) }}$ ) was the official monetary unit. To simplify, the conto $(=1,000,000$ reis) was also used as a unit of account. At this time, one conto was equivalent to £222 sterling approximately.
} 
picture they draw is of a high dispersion in loan size, average annual interest rates of about 8 percent, but ranging from 5 to 25 percent, and a length of commitment going from several months to 10 years, with a mean of around five years. Borrowers and lenders tended to be local, although some of the capital employed was drawn from further away.

Loans backed by material guarantees are known to have been practiced in Portugal centuries before the period we are considering. Their legal framework appears, however, to have been quite imperfect and to have made their use difficult and costly prior to its modernization in the $1860 \mathrm{~s} .{ }^{19}$ The compilation of the country's first Civil Code, in 1867, and the approval, in 1863, of a law establishing a national land registry eliminated many of these imperfections and, in theory at least, created conditions favourable to an expansion of mortgage credit and to its becoming cheaper and easier to use.

The advantages conferred by this new legal package were several. ${ }^{20}$ In the first place, the new civil code defined clearly the hierarchy of precedence of all debt obligations and placed mortgages high on this scale, well above most so-called 'ordinary credits', thus making them secure. It made the mortgage lien specific to a given asset and did away with the figure of the 'general mortgage', which used to fall on all of the debtor's real estate, consequently making it hard to distinguish between the rights of individual creditors. The lender was now able to know exactly which asset was assigned to his particular credit and was thus assured that until the resolution of the contract. This collateral would not serve to meet any other obligation. Creditors' rights were attached to the mortgaged object and no longer to the person of the debtor or to his estate. This meant that in case of a default, all they had to do was seize the guarantee, whoever

\footnotetext{
${ }^{19}$ A useful data base on pre-1800 Portuguese legislation is http://www.iuslusitaniae.fcsh.unl.pt/.

${ }^{20}$ This section is based on Vaz (1863), Sousa (1866) and the Civil Code itself. For a recent perspective, see Hespanha (2004).
} 
owned it, an easier task than pursuing judicially the debtor, who might no longer own the asset or be difficult to locate. Finally, in 1867, the civil code abolished the law of 1757 that had fixed the interest rate at 5 percent, and symbolically renamed what used to be called 'usury' as an 'onerous loan'. It also allowed the contracting parties to set the price of money freely. ${ }^{21}$ False contractual stipulations that inflated the principle of the loan in order to make it possible to actually charge higher prices than those allowed by law ceased, and this made the whole process less prone to abuses and irregularities.

To make these dispositions more effective, a national land registry was set up, with offices throughout the country, in which all properties, their attributes and value, their proprietors and the legal onuses incumbent upon them had to be formally inscribed. The inscription of these legal burdens was to be carried out in chronological sequence, so that precedence of obligations might be easily established and enforced, if necessary. Proper identification of the owners prevented others without authority from attempting to mortgage a property to which they had no legal title. Full publicity was given to the contents of the register. To ensure further transparency, any single property could only be entered in the office of the area where it was located. A specialised body of state functionaries was put in charge of these arrangements, and made liable to penalties in the event of any infringement of the rules.

The data to test our model come from the records of mortgage credit transactions carried out between the 1870 s and the 1910s and kept by the public notaries of the localities where they took place. They are currently held in the notarial collection of the Portuguese national archive (Arquivo Nacional da Torre do Tombo). Being legal records of contracts which were entered into freely and made before sworn public officials, they must be presumed to be reasonably reliable, particularly as they could

\footnotetext{
${ }^{21}$ See Hespanha (2004). Portugal followed most of Europe, where usury laws were abolished during the 1850s and 1860s. An exception was France, which kept the 5 percent ceiling until 1918! See Postel-Vinay (1998).
} 
serve later as proof in litigation. They cover the vast majority of occurrences of this sort because, with the exception of small amounts, all mortgage deals had to be the object of a notarized contract.

Each entry in the notary's ledger corresponds to a single debt. In most cases, it represents a new loan but in a few it was a 'confession of a debt' which had been contracted at an earlier date, without formality, and was therefore being restated, with proper legal solemnity, in order to secure the interests of those involved. ${ }^{22}$ Each entry usually contains the name, occupation and residence of the contracting parties. It also provides evidence of their civil status and capacity to sign. Besides this, it includes the interest rate charged, the amount of the debt, often the declared value of the collateral, the number of items of which the latter consisted and their location. The duration of the loan is mentioned too but rarely with the precision that would render this information useful. $^{23}$

Three benchmarks, for the periods 1874-6, 1894-6 and 1910-3, have been constructed with these data. They cover six counties in the district of Lisbon, namely Torres Vedras, Sintra, Arruda dos Vinhos, Alenquer, Mafra and Vila Franca de Xira, all of them located between 30 and 55 kilometres from the capital. At the time, the economic base of these administrative units was mainly agricultural, with a marked productive diversification into wine, cereals, olive oil, fruit and animal husbandry, and a strong orientation towards the market. They were essentially areas of dispersed small holdings and fairly densely populated. They were quite well connected, by road or railroad, to the small market towns of the region, and ultimately to Lisbon, but in none of these municipalities was there either a branch of a national bank or any local credit institution.

\footnotetext{
22 This was a common practice in eighteenth century France too. See Hoffman et al. (2000: ch.3).

23 Not infrequently this stipulation was 'at the will of the lender', other times 'for the rest of the life of the borrower', and more often still 'for a year and beyond'.
} 
Some Lisbon banks had correspondents there, indicating connections with a broader financial world, but they did not carry out credit operations, least of all with the farming community, which was thought too risky and suitable only for mortgage loans, which these institutions did not generally handle (Morais, 1889).

Not all entries are complete. The main lacuna occurs is the value of the collateral. In the cases of collateral consisting of landholdings already entered in the land registry office, notaries did not need to mention this value and recovering the information from the land registry itself has proved impossibly complex. Thus, although the data base contains some 1750 observations, we can only count on about 1150 for the tests requiring full information, all the same a satisfactory sample.

The profile which emerges tallies with the characteristics detected in earlier studies of similar regions in Portugal (Vaquinhas and Fonseca, 1983; and Fonseca, 1977). On average, loans were not large - between 200,000 and 300,000 $\underline{\text { reis }}^{24}$. The overwhelming majority of participants were local, borrowers and lenders often residing in the same parish, and transactions were entirely between individuals, except for a few involving charitable foundations as lenders. Although borrowers were more numerous than lenders, there would seem to have been no dominant players on either side of the relationship to distort competitive conditions. Having thus established that the conditions called for by the model formulated above appear to be satisfied, we can now turn to the discussion of the results of our three tests.

IV

\footnotetext{
24 The equivalent to between $£ 44$ and $£ 66$ sterling. In every county studied, there were a few large loans above one conto, that is $£ 222$.
} 
In comparative terms, Portugal's macroeconomic performance during the years from 1850 to 1913 left much to be desired. Although it had embarked on a process of sustained growth which was common throughout the Atlantic economy, by 1913 it was not only still at the bottom of the ranking in this group, but its per capita GDP had fallen from 60 per cent of the average for the most advanced economies to 35 per cent of the same (Amaral, 2002). Contemporary public opinion was naturally pessimistic about this economic inadequacy. It was not insensitive either to the institutional roots of these problems, be they in the political system, in the mechanisms of public administration, in the machinery of justice or in the provision of education (Ramos, 1994).

But were Portuguese institutions responsible to any extent for this weak economic performance? Were they worse than those of other countries at the time? Could they have delivered a better input in terms of the process of economic growth? In this section we attempt some preliminary answers to these questions, with the help of the results of the three tests outlined above in section II and applied to the data on mortgage contracts assembled for the period between 1873 and 1913. Our aim, first of all, is to determine whether the judicial system functioned poorly in Portugal compared to what might have been reasonably expected. Secondly, we try to place these findings in a broader international context, by comparing this with what happened elsewhere and therefore should have been practicable anywhere, including Portugal.

The first test focuses on the mean and dispersion of the interest rate charged on mortgage loans. As we saw earlier, one would expect that 'bad courts of law' would normally be associated with a high mean and a high variance in this variable. In one instance (panel 2, table 2), however, these characteristics could concur with 'good courts', if they coincided with loans in which the ratio (g) of the collateral to the loan value was low. The evidence marshalled in table 3 covers sixteen different situations in 
six counties at different points in time, plus three further benchmarks with incomplete information for Coimbra. It shows interest rate averages lay in a narrow range, from just over 7 to just over 9 percent. In the case of the 1342 contracts for which we have information on this item, the overall mean is 8.0 per cent and the standard deviation is 1.90.

\section{[table 3 about here]}

Was this too high a price for low-risk credits such as mortgage loans backed by solid real estate guarantee? Was the implicit risk premium excessive? Three domestic standards may be invoked for comparison. All of them have to do with low-risk financial applications. One comes from the Bank of Portugal, which discounted 90-day commercial paper, in Lisbon, normally at a rate of 5 per cent. Although this was first class paper, with two very good signatures, it was not free from default, and the Bank had occasionally to litigate to secure its interests. ${ }^{25}$ Nevertheless, it was probably one of the safest financial applications available. A second yardstick is the implicit return on government domestic bonds. This was perhaps a less secure asset and certainly more volatile, despite the state's guarantee, and its rate fluctuated between 4,1 and 6,4 per cent over the period (Esteves, 2002). The third was the return on the bonds issued by the Crédito Predial land bank to finance its mortgage loans, which was 6 per cent until 1880 and after that between 4 and 5 percent. These claims were backed by a stock of real estate worth at least twice the outstanding loans, as well as by the subscribed shareholder capital, and their market quotation deviated very little from par throughout the period (Marques, 1989). None of these 'safe' alternatives could be said to have been

\footnotetext{
${ }^{25}$ This discount rate was raised now and then but this was out of consideration for money market conditions rather than due to the riskiness of the paper taken.
} 
much less risky than contractualized mortgages on land and buildings. Significantly, however, their yield was two or three percentage points lower than the interest rates shown in table 3, a differential which is hard to reconcile with a high standard of judicial efficiency. ${ }^{26}$

As for the dispersion of the price of mortgage, the standard deviation and coefficient of variation data in table 3, at first sight, suggest that these rates were quite 'bunched up' around the mean. However, the fact that in all counties the maximum values of the distribution was between double and triple their minimum points to the existence of some very distant outliers. Obviously, the institutions that enforced these contracts were unable to countervail the hazard represented by 'marginal' borrowers, whose only chance of borrowing was to pay a high risk premium in a transaction which normally should have been free from this burden.

International comparisons are a second way of looking at the problem. These are not easy to come by in a field of research which has hardly been explored in the perspective adopted here. It is possible, nevertheless, to gather sufficient evidence to support the view that substantial discrepancies in mortgage rates existed between countries that could not be ascribed solely to differences between their respective prevailing interest rates. In the last decades of the nineteenth century, Sweden, Denmark and the Netherlands, all of them wealthier countries with a reputation for political stability and sound public administration, emerge as quite distinct from Portugal. In the first case, the average interest on mortgages was 5.5 percent, in the second they were 4.86 and in the Netherlands they lay between 4.5 and 5.0 percent. In Sweden, the nearly risk-free discount rate of the central bank varied between 4.2 and 5.0 percent, in Denmark it was

\footnotetext{
${ }^{26}$ The case of a large Alentejo landowner who, in 1890, was lending on mortgage at between 6 and 9 per cent, but placed money on deposit at the bank at 5 percent, corroborates the existence and scale of a risk premium on mortgage loans relative to more secure placements (Fonseca, 1992).
} 
3.7 per cent on average, while in the Netherlands, it was between 3.0 and 3.5 percent. In this group, there was clearly a much smaller risk differential than we find in Portugal. ${ }^{27}$ Spain's experience might be expected to be like that of Portugal. Not only were they similar in cultural, social and political backgrounds, but in that country too contemporary opinion saw mortgages as a risky business, in which the recovery of the principal could be often problematic (Carmona and Simpson, 2003). In fact, a significant risk premium is evident in Spain too. A study of the Mediterranean region of Murcia shows a mean interest rate for mortgages of approximately 9 percent in 1900-5 (Martinez Soto, 2001). Another, for Navarra, during an earlier period - 1858-82 comes up with a mean of 9,4 (Sabio Alcuten, 1996). Throughout the entire period, the discount rate of the Bank of Spain oscillated between 4,5 and 5,0 percent. ${ }^{28}$ Similarly, in two counties of the coffee booming economy of southern Brazil, a country of young and somewhat unpredictable institutions we find average interest rates on mortgages of over 11 per cent during the years from 1865 to 1887, while rates on 'safe' assets were between 5 and 6 per cent (Marcondes, 2002). ${ }^{29}$

The conclusion that the Portuguese differential for risk was large and dispersed, both by internal and by international standards within the Atlantic economy, thus validates the situation depicted in panels 2,3 and 4 of table 2 , but does not fit panel 1 .

\footnotetext{
${ }^{27}$ Central bank discount rates are from Homer and Sylla (1996) except for Denmark which are from Johansen (1985). Mortgage rates for Sweden are from Perlinge (2005), Hellgren (2003) and Hoppe and Langton (1994), for the Netherlands, from the Dutch Statistical Yearbook and for Denmark from data collected at the Landsarkivet for Sjaelland, Copenhagen.. The available data on available mortgage interest rates does not allow us to comment on measures of dispersion, except for Denmark, where the coefficient of variation on a hundred contracts between 1879 and 1895, in southern Zeeland was 0.108, less than half of the Portuguese figure.

${ }^{28}$ Even though based on a small sample of countries, a geographic pattern of 'judicial efficiency' comes to light from this exercise in comparison, and is suggestive because it matches other possibly relevant spatial distributions. Sweden and the Netherlands had not only better Justice but were also substantially richer than their Iberian counterparts. Moreover, their institutions, in general, were highly considered. On the other hand, Portugal and Spain were beset with reputations for political instability, clientelism, corruption and low human capital endowment, and their level of GDP per capita was of course much lower.

${ }^{29}$ For the Brazilian 'safe' rate, we used the yield on public gold bonds given by http://eh.net/databases/finance. There was no proto-central bank at this time in Brazil.
} 
Consequently, we turn now, for further clarification of our hypothesis, to our second test, which focuses on two classes of loans: those with a high $\mathbf{g}$ and those with a low one. Two issues arise. One is that of the relationship between the rate on interest of mortgage loans (r) and the ratio of guarantee-to-principal values (g). In the case of an 'inefficient' judicial system (panels 3 and 4), we would not expect any correlation between these two variables. With 'good' courts and a high value of $\mathbf{g}$ (panel 1), on the other hand, there would be a complete absence of any significant relationship between $\mathbf{r}$ and $\mathbf{g}$ - the lender would always recover all of the principle plus outstanding interest thanks to efficient judicial intervention. In contrast, with 'good' courts and a low value of $\mathbf{g}$ (panel 2), this variable ought to be negatively correlated with interest. Although lenders would anticipate an easy recovery of the guaranteed part of their loan in the event of a default, they still faced some risk, on its uncovered part. This would push the risk premium up somewhat, though less than the premium associated with "bad courts" (panels 3 and 4).

This brings up the second component of this test, which is whether the interest on wellguaranteed loans should be different from that on inadequately guaranteed ones. Mortgages with a low $\mathbf{g}$, if they were in panel 2 should have a lower mean interest than if they were in panel 3, which enjoyed no risk premium reduction. In fact, the latter's interest rate ought to be close to that for loans with a higher $\mathbf{g}$ and facing insufficient protection by the courts, namely those in panel 4. Grouping loans by the size of their $\mathbf{g}$ ratio and comparing the resultant interest means would therefore constitute another way of sorting our sample in the terms laid out in table 2.

We have considered two thresholds for the guarantee-to-principal ratio. One is a scenario where it is 2.0 , corresponding to the requirement imposed by the Portuguese Crédito Predial bank for its operations. In the other, $\mathrm{g}$ would be 1.5 , reflecting an 
assumption that local, informal lenders had comparatively better knowledge and consequently needed to protect themselves less from the search costs of the transaction than a Lisbon bank would. We follow the latter approach as being more plausible of the two.

A glance at table 4 shows that for $\mathbf{g}<1.5$ there is no correlation between $\mathbf{g}$ and $\mathbf{r}$. This definitely 'fails' panel 2 on this count, but satisfies the requirement, in this respect, of panel 3, which is that the two variables be uncorrelated. When we test this relationship for situations in which the collateral-to-debt ratio is 'adequate', both panels 1 and 4 come out well, that is there is no correlation with the interest rate. The second dimension of the test confirms this result. A two-sample z-test on the means of these two groups shows that, at the 5 percent significance level, the null hypothesis is verified. This means that loans with a smaller $\mathbf{g}$ had the same mean interest rate as those with the larger one and therefore might not be located in panel 2, but rather in panel 3 , where rates would be similar to those in panel 4.

At this point, it is difficult to claim that panels 1 and 2, corresponding to 'good courts', are completely ruled out, but it is clear that it is the situations involving 'bad courts' (panels 3 and 4) that have responded better to the tests conducted so far. We move on therefore to our third and decisive test.

The problem which arises now relates to the informational asymmetry which usually characterizes credit transactions. As a rule, lenders know less than borrowers about the capacity and inclination of the latter to meet their contractual obligations. It is also hard for them to ascertain whether the loan is being used to increase the productive capacity of the borrower and thereby rendering him more able to repay the amount borrowed. Mortgages, if properly enforced, are an efficient device for circumventing this difficulty but in the case we are considering, this remedy may not have been available. Creditors 
in this case would have had to overcome this knowledge gap by assessing the likelihood of a default directly on the basis of the personal attributes of the borrower. This would involve greater costs, as well as increased risks, both of which would have to be compensated by charging a premium (Guinnane, 2001). ${ }^{30}$ Our aim, with this third test, is to find out whether creditors, finding themselves unprotected by the courts of law, did indeed set interest rates which were not only higher but also related to borrowers' characteristics insofar as relevant to the risk they represented.

Three types of characteristics are pertinent to this exercise and jointly constitute vector A. One concerns the reputation of debtors for honesty and commitment to contractual obligations. Another refers to their material capacity to meet these obligations. A third has to do with features which were specific to the contract itself and affected transaction costs. It is extremely difficult to gather satisfactory historical evidence regarding the former. Nevertheless, we try here two possibilities. One is the participation in the transaction of co-signatories (cosign) who pledged their assets and personal reputation to the satisfaction of the borrower's obligation in the event of a default. From this paper's point of view, what is important is that this support may have signalled the borrower's standing in the community, since there would have been little sense in getting a co-signatory to risk his name and assets on behalf of someone whose character was deemed unreliable. On this reasoning, other things being equal, the presence of cosignatories, a dummy variable $(=1)$, should lower the interest rate and make the coefficient negative. The second possibility is the distance (distance), in kilometres, separating the abodes of the lender and borrower. This should measure how easy (or difficult) it was for the former to assess accurately the latter's reputation- in some

\footnotetext{
${ }^{30}$ Creditors were also less familiar with the nature and true worth of the collateral than the persons who pledged it. However, since these features were physical and directly observable, we assume that evaluating them would have had a far smaller cost than that of assessing the personal attributes of borrowers and would not have raised much the price of mortgage credit.
} 
contracts the parties to the contract lived in the same village, in others, 15 or 20 kilometres apart. The expectation is that this coefficient should be positive.

The contracts we have collected also contain items which may be used to proxy the second group of attributes that make up vector A. One of them is the amount borrowed (loan). A negative sign has been suggested by some of the literature for its coefficient on the grounds that the search cost for loans contained an important fixed element (Guinnane, 2001). Although plausible, this would have represented a very small expense given that the universe of loans was exiguous and therefore search costs were low. Our view instead is that larger loans were taken for investment purposes, by wellhealed borrowers with a good capacity to repay, while smaller ones tended to be contracted for reasons of economic survival and taken by penurious and less creditworthy agents (Svensson, 2001; Hoppe and Langton, 1994; Martinez Soto, 2001). Loan is therefore treated here as an indicator of the economic capacity that we are trying to detect in borrowers and its sign should be negative.

Two other personal attributes should contribute to the same end. One is the debtor's civil status (civ) - single, married or widower. The reasoning in this case is that in a peasant society, a married producer was likely to have a larger family labour force at his disposal and therefore be more robust economically (the dummy is $=1$ for married debtors, and $=0$ for other situations). The sign for this coefficient ought therefore to be negative. The other is human capital, which we proxy with an indicator of literacy (litdebt) ( $=1$ for those able to sign their names and $=0$ for those signing with a cross). This qualification was still relatively scarce in rural Portugal in contrast with nineteenth century rural Sweden, where it was strongly associated with financial and productive capacity (Nilsson et al, 1999). ${ }^{31}$ We see no reason to think otherwise in the case of

\footnotetext{
${ }^{31}$ In the late nineteenth century, the Portuguese literacy rate was 25 percent. The borrowers in our data base did about 15 percentage points better than this but lenders were about 70 percent literate.
} 
Portugal and so, again, an inverse relation with the interest rate and a negative coefficient are expected. ${ }^{32}$

Age, in this context, would be interesting too, although the sign of its coefficient is not unambiguous. It might have proxied physical vigour inversely and therefore productive capacity, but a longer life might also have favoured the observation of reputation, as well as the likelihood of a greater accumulation of material wealth and therefore of a greater security in loan transactions. Unfortunately, data for this are available for only a small number of cases and restricted to one county alone - Sintra, in the 1870 s - and they yield non-significant results anyway.

The interest rate on mortgages might have been affected by factors which were specific to the contracts themselves, rather than to the persons involved. They are worth taking into account nevertheless insofar as they impinged on transaction costs associated with the use of mortgages and would therefore have affected the price of the operation. One of them is the number of separate plots of land or buildings (nplot) which composed the collateral that underpinned the transaction. A smaller number would entail lower search costs for the lender and a lower interest rate, and conversely, with the result that the coefficient of this variable might be expected to be positive. A second feature of this kind is whether the mortgaged items had been entered into the new land registry (reg) created after 1863. Much property in the countryside was not registered until much later, owing to the cost, the burocratic difficulty and the distance from the land office. In the eyes of a lender, such assets would have been perceived as a less reliable guarantee, given the many forms of malfeasance to which the lack of registration could give rise.

\footnotetext{
32 We have included a dummy for the literacy of lenders, because it might be presumed that better educated lenders would be better at navigating through the intricacies of the machinery of justice and would therefore charge less on their loans. On the other hand, if this were the case, they could always charge the same as their less educated rivals and simply pocket the difference as a rent. In any case, this variable was tried and proved non-significant.
} 
In these cases, credit would have been relatively more expensive. With registered collateral, a mortgage would have attracted a lower rate of interest and hence we should expect a negative coefficient for this variable.

To make this analysis complete, it is necessary to consider whether geography had any influence on interest rates, a point suggested by the rate differences between localities shown in table 3 . The question is whether there were locational specificities which determined these variations in the price of credit, despite the physical proximity and socio-economic similarity between them. Could this be an aspect of institutional conditions or was it simply the result of market segmentation and contrasting local supply and demand conditions? To try and answer this question we used dummies for the four main towns in the sample, namely Torres Vedras (TV), Sintra (SNT), Vila Franca de Xira (VFX) and Mafra (MAF).

\section{[table 5 about here]}

From the point of view of the present analysis, the results of the OLS estimation presented in table 5 are important. All coefficients are individually significant at least at the 10 per cent level and two thirds of them are at the 1 per cent level. All but one (civ) have the expected sign and the F-statistic allows us to reject the null hypothesis of the coefficients being jointly equal to zero. The R2 is not particularly high, as one might expect given this is a panel data exercise, but suggests a reasonable explanatory power for the equation. It should be borne in mind that it is derived from historical data which were gathered by small-town notaries, who were often insufficiently qualified and may have worked according to not very consistent standards of exactitude (Silva, 1911). The implication is that mortgage interest rates were indeed influenced by the personal 
attributes of borrowers, who were made to pay a risk premium which reflected the risk they represented for their creditors. This is associated with the fact that lenders attached little value to the role of collateral in the mortgages they subscribed, a consequence, in turn, of their lack of trust in the judicial system. In terms of the model in table 2 , this means placing our data in panels 2,3 and 4, but not in panel 1 .

Besides personal attributes, interest rates emerge as being surprisingly influenced by locational specificities too, even though there was such a narrow geographic compass. Other things being equal, mortgages were dearer in Vila Franca de Xira and Mafra than in Sintra and Torres Vedras. It is tempting to invoke social and economic circumstances to explain these disparities but even the most obvious ones do not seem to provide a suitably coherent analysis. Distance from and accessibility to the large pool of savings in nearby Lisbon is a case in point and would proxy the supply side of this story, yet it fits poorly with the data. Greater proximity to the capital was not matched by cheaper credit. Per capita revenue from direct taxation is a variable that might have proxied demand side conditions convincingly, but also fails in practice to support a plausible interpretation. ${ }^{33}$ Alternatively, we might contemplate an institutional formulation according to which courts of law did significantly and consistently better in some places than others. This would be coherent with the main hypothesis of this study, namely that the machinery of justice in late nineteenth century Portugal was of poor quality. In this view, judicial inefficiency would mean not only underperforming in the enforcement of rights and contracts. It would also include a component of doing so in an erratic and unpredictable fashion. The conclusion would be that strongly significant locational dummies were just another manifestation of overall judicial inefficiency.

\footnotetext{
${ }^{33}$ Data for either are drawn from the Portuguese Statistical and Fiscal Yearbooks.
} 
Three of the variables initially considered - civ, dist and cosign - failed to yield the expected outcome. In the case of the civil status of borrowers (civ), the problem may be the misspecification of the variable. A married farmer and a widowed farmer may not have differed much after all in terms of the number of useful working relatives in the family. On the other hand, a young married farmer with small children could have been in a worse situation than a widower living with adult sons and daughters. Likewise, borrowers who were single and living in a 'fraternity', could have been better off too. The age/physical vigour of the head-of-family would have been a better characteristic to use, but unfortunately was unobservable, as already noted.

The irrelevance to the model of the distance between lender and debtor is probably the result of two distortions in the way in which we have measured Dist. One is that it was taken from a GPS reading between the head sites of the parishes to which the two parties belonged, rather than by measuring the distance between the true locations of their respective abodes. The extreme case is the value of zero attributed to pairs of contracting parties who lived in the same parish but who may have lived several kilometres apart. The second difficulty is that present day GPS paths probably differ from the historical trajectory between any two points to an extent that we cannot know today.

The failure of the co-signatory variable (cosign) to help explain the determination of the mortgage rate can best be seen as a problem of endogeneity. As formulated above, the existence of a third party guarantee could only affect lenders' perception of risk if they believed that the machinery of justice would deal efficiently with any defaulter, including the co-signatory. If they did not, the value to the creditor of the extra guarantee would have been minimal since anyone acting as a guarantor in a debt transaction, no matter how respectable might behave just as opportunistically as the 
defaulting borrower given the lack of credible sanctions. Perhaps for this reason, this was not a commonly used mechanism. Only 12 per cent of all contracts in our sample included co-signatories.

In contrast, registration of mortgaged property at the land office (reg) evoked the expected response. Why does this not contradict the 'judicial inefficiency' thesis nor raise another problem of endogeneity? The fact that an asset was officially described, with all its liens, and could be consulted did not in itself improve the likelihood of a successful foreclosure on a defaulting party. But it did provide the lender, at little cost, with reliable information on the status of the collateral. As a result, it lowered, not the risk premium, but the search cost of the transaction, which also had an impact on the mortgage rate. For this to occur, land offices must have been 'institutionally efficient', a condition which the market apparently considered to have been met, even if the courts of law themselves functioned poorly. The positive and significant coefficient of the reg variable, in table 5 , attests to this.

To sum up, table 6 gathers all the test results for our sample of mortgage contracts and organizes them into the panels in table 2 . It is clear that the data only fit properly the requirements of panels 3 and 4 , in other words, the situations in which courts were deemed to be 'bad'. This corroborates the view, shared by commentators and participants in the mortgage market of the late nineteenth century, that the existing machinery of justice performed poorly in protecting property rights and enforcing contracts. Indeed, in setting loan conditions, economic agents did not conduct their business as if they expected the full and prompt recovery of the principle in the event of a default. Institutions did matter and in this case their impact was negative.

[table 6 about here] 
It is widely believed that the institutional systems of the developed nations of the late nineteenth century Atlantic economy were basically similar. It is thought that these countries were moulded by the same blue print and that whatever discrepancies existed were hardly sufficient to explain differences in economic performance. The present study contends that these countries were institutionally more diverse than has been supposed and that this contributed to some of the divergence in growth observed between them. To clarify this issue, we have focused on the efficiency of the machinery of justice. This is of interest not only because its design displayed a notable appearance of uniformity among polities, but also because neo-Institutionalists have held the judicial system to be a key institutional factor for growth.

Given the parsimony of information in this field of historical research, the topic has had to be explored by indirect means. Its limits were drawn around the behaviour of economic agents in small scale mortgage credit markets, with our data coming from six counties in provincial Portugal, between the 1870 s and the 1910s. Based on nearly eighteen hundred mortgage contracts, three tests were devised to allow us to determine whether lenders found that judicial institutions were good at enforcing contracts and enforcing property rights. The conclusions from such a narrow area of analysis can arguably be extended to the machinery of justice in Portugal as a whole, and the method seems robust enough that it can serve for comparative, international purposes too.

All three tests show that the loan policy followed by these money lenders was contradictory with a high level of trust in the efficiency of the courts. In the first place, interest rates were excessively high, and there was too much dispersion around the 
mean. This implies that they were set in the expectation that the collateral would not give adequate security in the event of default. In this respect, Portugal differed sharply from Sweden, Denmark and the Netherlands and was very similar to Spain and Brazil, suggesting that a North-South divide was already then present in terms of institutional quality.

The second and the third tests confirm this perception. Creditors negotiated their loans in the same way, whether the security pledged was adequate or not to cover the risk of the operation. This leads us to infer that they expected relatively little from the thirdparty contract enforcement power of the courts. This is corroborated by the fact that creditors showed themselves sensitive to the personal attributes of borrowers as indicators of the likelihood of a successful settlement of the loan. The interest rate was lower for borrowers whose attributes indicated a greater capacity and willingness to repay, and higher for those who seemed less promising from this point of view.

This research has still a long way to go, namely by extending it to other countries along the lines developed here. In the meantime, two final questions should be posed. The first is whether any evolution occurred in terms of institutional quality during the four decades which we have scrutinized? It is tempting to read an improvement in judicial efficiency into the gradual reduction in mean interest rates from the 1870s to the 1910s registered in table 3. But there are other circumstances to consider. Land registration was spreading rapidly during this time span - in Vila Franca de Xira, for example, it rose from 35 to 86 per cent of all real estate pledged - and this would account for at least some of the reduction in mean interest rates. In the second place, it is not unlikely that access to financial resources in nearby Lisbon was on the rise, as communications improved and financial institutions developed. The specific contribution of improvements at the level of the courts may therefore have been rather slight. 
The second question seeks to reconcile the existence of an active mortgage market with the poor showing of the courts of law which were supposed to underpin its operation. In this matter, two issues commend themselves to our attention. One is that the courts may have functioned imperfectly, but they were not inexistent. Some remedy was obtainable from them against prevaricators, but we suppose it cost a considerable amount of time and money. The high interest rates we have detected reflect the high costs associated with default because of an adverse institutional environment. It does not imply that these economic agents were struggling in a Hobbesian environment. At the same time, lenders apparently welcomed borrowers who owned adequate collateral, and were prepared to charge them less than they would have for 'personal' unsecured credit, protected by nothing other than the reputation of the debtor. Undoubtedly, these courts made some difference after all. Even though mortgage contracts were probably more costly to both parties, and certainly more complicated burocratically, they may have seemed a useful selection mechanism for lenders. For borrowers who owned assets, they offered a chance of a lower interest rate. In a world of small peasants, many of whom needed finance but had nothing to pledge, there was nothing left but to pay a 'usurious' interest rate, the only one that in their case the market would bear.

\section{References}

Acemoglu, Daron, Johnson, Simon and Robinson, James A., (2001), 'The Colonial Origins of Comparative Development: An Empirical Investigation', American Economic Review, 91, pp. 1369-1401.

Acemoglu, Daron, Johnson, Simon and Robinson, James A., (2002), 'Reversal of Fortune: Geography and Institutions in the Making of the Modern World Income Distribution', Quarterly Journal of Economics, 117, pp. 1231-94.

Allen, Robert C. (2003), 'Progress and Poverty in Early Modern Europe' Economic History Review, LVI, pp. 403-443. 
Amaral, Luciano (2002), 'How a Country Catches Up: Explaining Economic Growth in Portugal in the Post-War Period (1950s to 1973)', Ph.D. dissertation, European University Institute.

Baumol, William (1986), 'Productivity Growth, Convergence and Welfare: What the Long-Run Data Show', American Economic Review, 76, pp. 1072-85.

Bordo, Michael D., Taylor, Alan M. and Jeffrey G. Williamson (eds) (2003), Globalization in Historical Perspective Chicago: University of Chicago Press).

Brettell, Caroline B. (1991), 'Moral Economy or Political Economy? Property and Credit Markets in $19^{\text {th }}$ Century Rural Portugal', Journal of Historical Sociology, 12, pp. $1-28$.

Cabral, Célia, and Pinheiro, Armando (1999), 'Credit Markets in Brazil: The Role of Judicial Enforcement and other Institutions', Inter-American Development Bank Working Paper R-368.

Carmona Pidal, Juan and Simpson, James (2003), El Laberinto de la Agricultura Española: Instituciones, Contratos y Organizacion entre 1850 y 1936 (Zaragoza: Prensas Universitárias de Zaragoza).

Clague, Christopher, Keefer, Philip, Knack, Stephen and Mancur Olson (1999), 'Contract-Intensive Money: Contract Enforcement, Property Rights and Economic Performance', Journal of Economic Growth, 4, pp.181-211.

Crafts, N. R. F. (2000), "Institutional Quality and European Development before and after the Industrial Revolution", Paper presented at the World Bank Summer School, Washingto DC, July 17-19, 2000.

Djankov, Simeon, La Porta, Rafael, Lopez-de-Silanes, Florencio and Andrei Shleifer (2003), 'Courts', Quarterly Journal of Economics, 118, pp. 453-517.

Esteves, Rui Pedro (2002), Finanças Públicas e Crescimento Económico. O Crowding Out em Portugal da Regeneração ao Final da Monarquia (Lisboa: Banco de Portugal).

Finer, Samuel (1997), The History of Government, vols I-III (Cambridge: Cambridge University Press).

Fonseca, Fernando Taveira da (1977), 'O Crédito Privado em Coimbra no Ano de 1885 Visto a Partir dos Actos Notariais: Alguns Aspectos', Boletim do Arquivo da Universidade de Coimbra, III, pp. 161-225.

Fonseca, Hélder Adegar (1992), Economia e Atitudes Económicas no Alentejo Oitocentista, Ph.D. dissertation, University of Évora.

Fonseca, Hélder Adegar (1996), O Alentejo no Século XIX. Economia e Atitudes Económicas (Lisboa: Imprensa Nacional).

Foreman-Peck, James (1995), 'A Model of Later Nineteenth Century European Economic Development', Revista de Historia Economica, 13, pp.441-71. 
Foreman-Peck, James and Lains, Pedro (2000), 'European Economic Development: The Core and the Southern Periphery, 1870-1910', in J. G. Williamson and S. Pamuk (eds), The Mediterranean Response to Globalization before 1950 (London and New York: Routledge).

Glaeser, Edward, La Porta, Rafael, Lopez-de-Silanes, Florencio and Shleifer, Andrei (2004), 'Do Institutions Cause Growth?', Journal of Economic Growth, 9, pp. 271-303.

Guinnane, T. (2001), 'Cooperatives as Information Machines: German Rural Credit Cooperatives, 1883-1914', Journal of Economic History, 61, pp. 366-89.

Guinnane, T. (1994), ‘A Failed Institutional Transplant: Raiffeisen's Credit Cooperative in Ireland, 1894-1914', Explorations in Economic History, 31, pp. 38-61.

Gunnarsson, Christer (1991), 'What is New and What is Institutional in the New Institutional Economics? An Essay on Old and New Institutionalism and the Role of the State in Developing Countries', Scandinavian Economic History Review, 39, pp. 43-67.

Hellgren, Helga (2003), Fasta Förbindelser. En Studie av Låntagare hos Sparbanken och Informella Kreditgivare I Sala 1860-1910 (Uppsala: Uppsala Studies in Economic History).

Hespanha, António Manuel (2004), Guiando a Mão Invisível: Direitos, Estado e Lei no Liberalismo Monárquico Português (Coimbra: Almedina).

Hoffman, Philip T., Postel-Vinay, Giles and Jean-Laurent Rosenthal (2000), Priceless Markets. The Political Economy of Credit in Paris, 1660-1870 (Chicago and London: Chicago University Press).

Homer, Sidney and Sylla, Richard (1996), A History of Interest Rates $\left(3^{\text {rd }}\right.$ edition, New Brunswick, N.J.: Rutgers University Press).

Hoppe, Göran, and Langton, John (1994), Peasantry to Capitalism. Western Östergötland in the Nineteenth Century (Cambridge: Cambridge University Press).

Johansen, Hans Christian (1985), Dansk Økonomisk Statistik 1814-1980 (Copenhagen: Gyldendal).

Kauffman, Daniel, Kraay, Aart and Zoido-Lobaton, Pablo (2002), 'Governance Matters II. Updated Indicators for 2000/01’, World Bank Policy Research Working Paper 2772.

La Porta, Rafael, Lopez-de-Silanes, Florencio, Shleifer, Andrei and Robert Vishny (1999), 'The Quality of Government', Journal of Law, Economics and Organization, 15, pp. 222-79.

Lindgren, Håkan (2002), 'The Modernization of Swedish Credit Markets, 1840-1905: Evidence from Probate Inventories’ Journal of Economic History, 62, pp. 810-32.

Marcondes, Renato Leite (2002), 'O Financiamento Hipotecário da Cafeicultura no Vale do Paraíba Paulista (1865-87)’, Revista Brasileira de Economia, 56, pp.147-70. 
Marques, A. H. de Oliveira (1989), Companhia Geral de Crédito Predial Português. 125 Anos de História (Lisboa, n.e.).

Marshall, Monty G. and Jaggers, Keith (2002), 'Polity IV Project. Political Regime Characteristics and Transitions 1800-2002', Center for International Development and Conflict Management, University of Maryland.

Martinez Soto, Angel Pascual (2001), 'La 'Tela de Araña'. Mercados Informales de Financion Agrária, Usura y Crédito Hipotecário en la Region de Múrcia (1850-1939)', Áreas. Revista de Ciências Sociales, 21, pp.185-220.

Mauro, Paolo (1995), 'Corruption and Growth', Quarterly Journal of Economics, 110, pp.681-712.

Mitchell, Brian R. (1996), British Historical Statistics (Cambridge: Cambridge University Press).

Morais, Paulo (1889), Inquérito Agrícola. Estudo Geral da Economia Rural da $7^{\text {a }}$ Região Agrícola (Lisboa: Imprensa Nacional).

Nelson, Richard R. and Sampat, Bhaven N. (2001), 'Making Sense of Institutions as a Factor Shaping Economic Performance', Journal of Economic Behaviour and Organization, 44, pp.31-54.

Nilsson, A., Pettersen, L. and Svensson, P. (1999). Agrarian transition and literacy: the case of nineteenth century Sweden. European Review of Economic History 3, pp.79-96.

North, Douglass C. (1990), Institutions, Institutional Change and Economic Performance (Cambridge: Cambridge University Press).

O'Rourke, Kevin H. and Williamson, Jeffrey G. (1997), 'Around the European Periphery 1870-1913: Globalization, Schooling and Growth', European Review of Economic History, 1, pp.153-90.

O'Rourke, Kevin H. and Williamson, Jeffrey G. (1999), Globalization and History: The Evolution of a Nineteenth Century Atlantic Economy (Cambridge, Mass.: MIT Press).

Pamuk, Sevket and Williamson, Jeffrey G. (eds), The Mediterranean Response to Globalization before 1950 (London and New York: Routledge).

Perlinge, Anders (2005), Sockenbankirerna. Kreditrelationer och Tidig Bankversamhet: Vånga Socken I Skåne 1840-1900 (Stockholm: Nordiska Museets Förlag).

Postel-Vinay, Gilles (1998), La Terre et l'Argent. L'Agriculture et le Crédit en France du XVIIIe au Début du XXe Siècle (Paris: Albin Michel).

Prados de la Escosura, Leandro and Sanz Villaroya, Isabel (2006), 'Contract Enforcement and Argentina's Long-Run Decline', Working Paper WP 06-06, Department of Economics, Universidad Carlos III, Madrid. 
Ramos, Rui (1994), A Segunda Fundação. História de Portugal, vol.VI (Lisboa: Estampa).

Reis, Jaime (2005a), 'Institutional Factors and Economic Growth during the First Era of Globalization: What Can We Do with Them?', Inaugural Lecture, VIII Congress of the Spanish Association of Economic History, Santiago de Compostela, $13^{\text {th }}-16^{\text {th }}$ September, 2005.

Reis, Jaime (2005b) , 'Los Sistemas Financieros de la Periferia: Una Comparacion entre Escandinavia y el Sur de la Europa durante el Siglo XIX', Papeles de Economia (2005), 105/6, pp.109-29.

Rodrick, Dani, Subramanian, Arvind and Francesco Trebbi (2004), 'Institutions Rule: The Primacy of Institutions over Geography and Integration in Economic Development', Journal of Economic Growth, 9, pp.131-65.

Rodrigues, João Albino de Sousa (1929), A Companhia Geral do Crédito Predial Portuguez. Estudo Descritivo e Crítico da sua Vida (Lisboa: Sociedade Nacional de Tipografia).

Rose, Richard (2000), International Encyclopedia of Elections (Basingstoke: MacMillan).

Sabio Alcuten, Alberto (1996), Los Mercados Informales de Credito y Tierraen una Comunidad Aragonesa (Madrid: Banco de España).

Sgard, Jerome (2006), 'Do Legal Origins Matter? The Case of Bankruptcy Laws in Europe 1808-1914', European Review of Economic History, 10, pp. 389-419.

Silva, Eugénio (1911), Os Escrívães-Notários perante as Reformas Judiciais e do Notariado (Lisboa: Tip. Libanio da Silva).

Silva, Maria Júlia de Oliveira e (1994), Crédito Hipotecário em Santarém durante a Regeneração (1851-56) (Santarém: Câmara Municipal de Santarém).

Smith, Adam (1776, 1990), An Inquiry into the Nature and Causes of the Wealth of

Nations (London: Encyclopaedia Britannica).

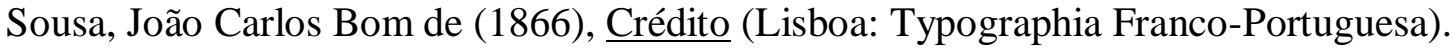

Svensson, Patrick (2001), Agrara Entreprenörer. Böndernas Roll i Omvandlingen av Jordbruket i Skåne 1800-1870 (Lund: Lund Studies in Economic History).

Ulrich, João Henrique (1908), O Crédito Agrícola em Portugal (Lisboa: Ferin).

Vaquinhas, Irene Maria (1982), 'O Credito Hipotecário em Coimbra no Ano de 1866. Tentative de Integração no Desenvolvimento Capitalista do Século XIX, Boletim do Arquivo da Universidade de Coimbra, IV, pp. 39-84. 
Vaquinhas, Irene Maria e Fonseca, Fernando Taveira da (1984), 'Formas de Investimento de Capital. Crédito Privado e Crédito Publico em Coimbra no Terceiro Quartel do Século XIX, Revista Portuguesa de Historia, XX, pp. 99-139.

Vaz, José Joaquim Fernandes (1863), Do Crédito Predial. Resposta aos Pontos propostos pela Faculdade de Direito da Universidade de Coimbra (Combra: Typographia da Universidade). 


\section{Table 1}

Institutional characteristics of West European countries

1

Polity, 1870

\section{Austria}

Belgium

Denmark

Finland

France

Prussia/Germany

Greece

Ireland

Italy

Netherlands

Norway

Portugal

Spain

Sweden

Switzerland

UK

mean

sd

$\max$

$\min$
$-4$

6

$-3$

8

8

2

10

8

$-1$

$-2$

10

2

6

$-4$

10

8

3.3

1.4

10

$-4$
2

Franchise, $1870 \quad$ Contract-intensive (percent of population) money, 1913

(CIM)

30.0

37.7

29.0

8.3

43.2

0.75

38.3

0.91

30.5

na

28.9

na

12.3

0.70

21.2

0.66

34.8

0.92

25.3

0.37

35.7

0.31

12.7

0.92

28.5

0.92

28.5

0.97

27.8

0.78

9.9

0.77

43.2

0.97

8.3

0.31

Sources: see text

Notes: $\mathrm{Cim}=(\mathrm{M} 2-\mathrm{C}) / \mathrm{M} 2$ 


\section{Table 2}

The Model: four scenarios of institutional/ economic interaction in mortgage markets

adequate guarantee

Panel 1

"Good"

courts

r: low value, low variance

$r$ uncorrelated with $\mathrm{g}$

$r$ uncorrelated with $A$

\section{Panel 4}

"Bad"

courts

$r$ : high level, high variance

$r$ uncorrelated with $g$

$r$ correlated with $A$ inadequate guarantee

\section{Panel 2}

r: high value, high variance $r$ correlated negatively with $g$

$r$ correlated with $A$

Notes: $\quad r=$ rate of interest on loans;

$g=$ ratio of mortgage to debt values

$A=$ vector of attributes of borrowers, lenders and contracts

Sources: see text and table 3 


\section{Table 3}

Mortgage interest rates: mean and dispersion

$\underline{\text { mean }}$

10.7

Alenquer, 1870s

Arruda dos Vinhos,

1870 s

Mafra, 1870 s

Mafra, 1890s

Mafra, 1910s

Sintra, 1870 s

Sintra 1890s

Sintra 1910s

Torres Vedras, 1870s

Torres Vedras, 1890s

Torres Vedras, 1910s

Vila Franca de Xira,

1870s

Vila Franca de Xira,

1890s

Vila Franca de Xira,

1910s

All
8.0

9.3

9.2

8.2

8.2

7.3

7.8

7.6

8.6

7.7

7.4

9.0

9.1

8.0

8.4

7.5
8.1 standard

deviation

3.16

2.14

2.06

1.87

1.38

1.56

1.23

1.28

2.69

1.48

1.15

2.83

2.42

1.86

1.90

0.237

0.159

0.168

0.313

0.191

0.155

0.314

0.266

0.232

10

17.0

4.8

Coimbra, 1873

Coimbra, 1878

Coimbra, 1885 na

na

na na

na

na
20.0

5.0

\section{0}

5

5.0

4.0

4.8

4.8

.0

4.5

.0

5.0

\section{.0}

5

\section{.0}

Sources: Arquivo Nacional da Torre do Tombo (Lisbon), Colecção Notários, except for Coimbra/1873 and 1878, which are from Vaquinhas and Fonseca (1983), and Coimbra/1885, which is from Fonseca (1977). 


\section{Table 4}

Correlations between the rate of interest and the $\boldsymbol{g}$ ratio

$\underline{\text { Correlation }} \underline{\text { Sign }}$

$g>1,5 \quad$ no $(0.004)$

$\mathrm{g}<1,5 \quad$ no $(0.006)$

Note: value of $\mathrm{R} 2$ in brackets

Sources: the same as for table 3 


\section{Table 5}

Determinants of the interest rate of mortgage contracts, 1870 s to 1910 s

Dependent variable: interest rate

(ordinary least squares regression)

Explanatory Variables (expected signs in brackets)

C

$10.067^{* * *}$

(54.13)

Loan (-)

$-0.807^{* * *}$

$(-4.821)$

Civ (-)

$0.212^{*}$

(1.799)

Litdebt (-)

$-0.487^{\star \star *}$

Nplot (+)

$0.062^{*}$

(1.651)

$\operatorname{Reg}(-)$

$-0.211^{*}$

$(-1.716)$

TV

$-2.095^{\star * *}$

$(-10.004)$

SNT

$-2.154^{* * *}$

$(-10.682)$

MAF

$-1.748^{\star * *}$

(.8.806)

VFX

$-1.147^{* * *}$

$(-5.412)$

R2

0.161

F-statistics

24,298

Prob (F-statistic)

0.000

$\mathrm{N}$

1153

Sources: see text

Notes: t-statistics in brackets;

loans in millions of reis; civ dummy - married $=1$, single or widower $=0$; lit dummy - can sign $=1$, cannot sign $=0$; reg dummy - registered collateral $=1$, not registered collateral $=0$; cosign dummyhas cosignatory $=1$, no cosignatory $=0$; TV- Torres Vedras; SNT- Sintra; MAF - Mafra; VFX - vila Franca de Xira 
Table 6

Statistical test results and the panels of table 2

$\underline{\text { Test1 }}$

Panel 1

Panel 2

Panel 3

Panel 4

Sources: see text

no

yes

yes

yes $\underline{\text { Test } 2}$

$\underline{\text { Test } 3}$ yes

no

yes

yes no

yes

yes

yes 